Volume 2 Issue 2, July-December 2021: pp.137-148.

Faculty of Law, Universitas Lampung, Bandar Lampung, Indonesia. http://jurnal.fh.unila.ac.id/index.php/ip

P-ISSN: 2723-2638 E-ISSN: 2745-9314

\title{
Implementation of Compensation Claim's Mechanism through Pretrial for Error in Persona in the Criminal Justice System
}

\author{
Feryando \\ North Lampung District Attorney, Indonesia \\ f3ry4ndo@gmail.com
}

Submitted: Jan 28, 2021; Reviewed: Jun 29, 2021; Accepted: Sep 16, 2021

Article's Information
keywords:
Compensation; Error in Persona;
Pretrial.

DOI :

https://doi.org/10.25041/ip.v2i2.2234
An error in persona in the implementation of the criminal justice system is a type of destructive action by law enforcement officers that can cause harm to someone. The use of authority by investigators to arrest and detain and detention and prosecution by public prosecutors is a concrete form of persona error. This study focused on the mechanism of a compensation claim through pre-trial due to a persona error in implementing the criminal justice system and an impediment to the implementation of the pre-trial judge's decision on the granting of the compensation claim. The method used is normative and empirical juridical research. The results showed that the mechanism of a claim for compensation through pre-trial due to an error in person in implementing the criminal justice system was carried out fundamentally at the formulation stage. These formulations outlined in the Code Of Criminal Procedure (Kitab Undang-Undang Hukum Acara Pidanal KUHAP) and Government Regulation Concerning Implementation of The Book of Criminal Procedure Law as a basis for the implementation of pre-trial and the application stage. The statutory factors of Decree of the Minister of Finance of the Republic of Indonesia Number: 983 / KMK.01 / 1983 (Keputusan Menteri Keuangan RI Nomor 983/KMK.01/1983) are an impediment in implementing the pre-trial judge's determination of the compensation claim because the regulation 
governs administrative procedures that are lengthy

and involve government agencies.

\section{A. Introduction}

The implementation of the criminal justice system is a series of processes carried out by law enforcement officials starting from the occurrence of a suspected criminal act until the imposition of a court decision. The main purpose of criminal justice is to decide whether a person is guilty or not through a procedure bound by the rules of evidence. ${ }^{1}$ This is to prevent mistakes in persona from being arrested, detained, prosecuted and tried concerning the criminal acts accused of him. Furthermore, the efforts made to assist in the termination process reflect the purposeful behavior of the person who committed the act. ${ }^{2}$ The cause of people committing a crime is not without cause, the condition of profound economic and cultural disparities in society to provide opportunities for some people. Mobility can turn into an element of commodification when people have to move to earn a living. ${ }^{3}$ The relationship between the determinants of subjective well-being related to crime in two dimensions, namely life satisfaction and crime-related factors, namely experience victimization and feelings of security, are essential determinants of subjective well-being. However, different patterns in the relationship between the dimensions of well-being and crime-related factors were revealed. ${ }^{4}$

Implementing a compensation claim suffered by a person or group of people as a legal subject caused by the actions of a person or an agency/institution through a court is a right protected by law. Compensation is included in the scope of pretrial cases. Those who are harmed by law must be given compensation and rehabilitation following the judicial system. This means that compensation claims can be submitted through a process in a pretrial trial in a district court due to detrimental actions at the level of investigation by the police, prosecution at the prosecutor's office and trial in court.

The occurrence of an error in persona in implementing the criminal justice system is a form of destructive action by law enforcement officers that impacts causing harm to someone. Oostinga et al. distinguished three types of communication errors: contextual, factual, and judgmental. Messages relating to police practices or procedures are examples of contextual errors. Messages that contain an error fact and are objectively incorrect are considered factual errors. ${ }^{5}$ Identifying a situation as a crime is associated with solid moral disapproval, resulting in harsher punishments. ${ }^{6}$ The concrete form of error in persona in this study is related to the authority to arrest and detain investigators and detention and prosecution by the public prosecutor. Regarding this matter, the author uses the example of Oman Abdurahman Bin Kasnan, who has been arrested, detained and prosecuted and tried at the Kotabumi District Court on charges of committing theft with violence.

In connection with this case, through the decision of the Kotabumi District Court Number

\footnotetext{
${ }^{1}$ Hasuri Hasuri, "Sistem Peradilan Pidana Berkeadilan Melalui Pendekatan Kontrol Dalam Proses Penegakan Hukum," Ajudikasi: Jurnal Ilmu Hukum 3, no. 2 (December 31, 2019): 167-84, https://doi.org/10.30656/ajudikasi.v3i2.1879.

2 Damon M. Petrich, "A Self-Determination Theory Perspective on Human Agency, Desistance from Crime, and Correctional Rehabilitation," Journal of Developmental and Life-Course Criminology 6, no. 3 (September 1, 2020): 353-79, https://doi.org/10.1007/s40865-020-00141-9.

${ }^{3}$ Sandra Seubert, "Shifting Boundaries of Membership: The Politicization of Free Movement as a Challenge for EU Citizenship," European Law Journal 26, no. 1-2 (March 1, 2020): 48-60, https://doi.org/10.1111/eulj.12346. ${ }^{4}$ Eva Krulichová, "Changes in Crime-Related Factors and Subjective Well-Being over Time and Their Mutual Relationship," International Journal of Law, Crime and Justice 65 (June 1, 2021): 100-457, https://doi.org/10.1016/j.ijlcj.2021.100457.

${ }^{5}$ M.D. Oostinga, Ellen Giebels, and Paul J. Taylor, "Communication Error Management in Law Enforcement Interactions: A Receiver's Perspective," Psychology, Crime \& Law 24, no. 2 (2018): 134-55, https://doi.org/10.1080/1068316X.2017.1390112.

${ }^{6}$ Stefan Machura et al., "Recognizing Modern Slavery," Journal of Human Trafficking 5, no. 3 (July 3, 2019): 201-19, https://doi.org/10.1080/23322705.2018.1471863.
} 
15/Pid.B/2018/PN.Kbu Jo. Supreme Court decision Number 129 K/Pid.2019 defendant Oman Abdurahman Bin Kasnan was found not guilty and acquitted of the public prosecutor's indictment. The reason is insufficient evidence that Oman Abdurahman Bin Kasnan was the perpetrator of the criminal act of theft with violence charged by the public prosecutor. As a reaction to the decision, Oman Abdurahman Bin Kasnan, who was originally a suspect and the defendant, filed a compensation claim. The claim was made through a pretrial mechanism at the Kotabumi District Court against the leadership of the North Lampung Police as the investigator's superior who had named him a suspect and made arrests and detentions. The compensation claim was also submitted to the leadership of the North Lampung District Attorney as the superior of the public prosecutor, who had determined him as a defendant and carried out detention and prosecution at trial.

Based on the claim for compensation, the pretrial judge in case Number 1/Pid.Pra/2019/PN.Kbu on June 17, 2019, ruled that Oman Abdurahman Bin Kasnan was entitled to receive compensation in the amount of Rp.222.000.000 (two hundred twenty-two million rupiahs) as a result of the North Lampung Police investigators and the North Lampung District Attorney's General Prosecutor's fault in making arrests, detentions and prosecutions. The examples of the cases mentioned above are factual evidence that acts of error in persona in connection with the use of authority in arrests, detentions and prosecutions still often occur. Although the Criminal Procedure Code has comprehensively regulated the mechanism for the use of authority by investigators and public prosecutors, the act of error in persona has become a problem inherent in the criminal justice system due to the inaccuracy of investigators and public prosecutors. Political and economic developments have also profoundly changed the constellation of legal pluralism, following diverse trajectories in which the concept has acquired multiple meanings. ${ }^{7}$

Pretrial is a means of horizontal control to test the legitimacy of the use of authority by law enforcement officers. ${ }^{8}$ In addition, the purpose of pretrial is to uphold the law and protect human rights for suspects at the level of investigation and prosecution. ${ }^{9}$ One of the concretizations of the protection guarantee is in the form of fulfilling the right to compensation due to an error in persona based on Article 95 paragraph (1) of the Criminal Procedure Code, which is applied through a pretrial process. Compensation is a fulfilment tool to compensate for losses due to loss of enjoyment in the form of freedom due to forced efforts not based on law. ${ }^{10}$ For this matter, the Criminal Procedure Code has confirmed that compensation claims can be accommodated through a pretrial examination at a district court submitted by a suspect, defendant or convict.

Normative legal research is legal research conducted by examining library materials or secondary data. The urgency of this research is based on the pretrial mechanism in the Criminal Procedure Code for this purpose. This study focuses on claiming compensation's mechanism through pretrial due to an error in persona in the criminal justice system's implementation. Moreover, it discusses the inhibiting factors in implementing the pretrial judge's determination of the granting of the claim for compensation which was reviewed using the normative-

\footnotetext{
${ }^{7}$ Keebet von Benda-Beckmann and Bertram Turner, "Legal Pluralism, Social Theory, and the State," Journal of Legal Pluralism and Unofficial Law 50, no. 3 (September 2, 2018): 255-74, https://doi.org/10.1080/07329113.2018.1532674.

8 Yusi Amdani, "Implikasi Penafsiran Undang-Undang Oleh Hakim Praperadilan Dalam Perkara Tindak Pidana Korupsi," Mimbar Hukum - Fakultas Hukum Universitas Gadjah Mada 27, no. 3 (February 10, 2016): 459, https://doi.org/10.22146/jmh.15872.

${ }^{9}$ Alfitra Alfitra, "Disparitas Putusan Praperadilan Dalam Penetapan Tersangka Korupsi Oleh KPK," Jurnal Cita Hukum 4, no. 1 (June 21, 2016): 73-86, https://doi.org/10.15408/jch.v4i1.3201.

${ }^{10}$ Syarif Abdul Rohman and Umi Rozah, "Kebijakan Kriminal Mengenai Pemberian Ganti Kerugian Terhadap Korban Salah Tangkap," Jurnal Pembangunan Hukum Indonesia 2, no. 1 (January 10, 2020): 117-28, https://doi.org/10.14710/jphi.v2i1.117-128.
} 
empirical legal research method. In contrast, empirical research is a research method that reviews the function of a law or rule in terms of its application in the community.

\section{B. Discussion}

\section{Mechanism Compensation's Claims through Pretrial Due to Errors in Persona in the Criminal Justice System's Implementation}

The involvement of a person in a criminal case with the status of a suspect or defendant will have a very significant effect on them. This influence generally arises from the negative view of society even though the person is subsequently found not guilty of the crime initially charged to them. This, of course, can be considered as a form of loss, especially in the process of examining a criminal act that has previously been subject to forced efforts in the form of arrest and detention so that the person in question has the right to obtain justice for himself which can be pursued through filing for compensation based on Article 95 paragraph (1) of the Criminal Procedure Code.

Compensation in the Criminal Procedure Code has a vital role in fulfilling the rights of the suspect, defendant or convict as a party experiencing suffering due to an error in persona in implementing the criminal justice system. Compensation is the right of a person to obtain fulfilment in the form of a sum of money because he is arrested, detained, prosecuted or tried without any reason based on law or because of an error regarding the person or the law applied. Thus the main aspect of filing a compensation claim is fulfilling an element of error in exercising authority. ${ }^{11}$ However, compensation must first be preceded by filing a claim. ${ }^{12}$

The suspect and the defendant have been placed under the Criminal Procedure Code in the position of his entity and dignity as a human being, which must be adjusted to the noble values of humanity. ${ }^{13}$ The attachment of these rights should serve as signs for investigators and public prosecutors so that there is no in-person error in establishing a person as a suspect accompanied by arrest and detention, which will then be prosecuted before the trial to minimize the submission of claims for compensation by the suspect defendant and convict.

The filing of a claim for compensation to the district court, which is held through a pretrial examination process, is based on the main objective so that the applicant obtains a judge's determination, considering that pretrial is an institution authorized by the Criminal Procedure Code as a counterweight to the powers of investigators, investigators and public prosecutors so that the said authority can be carried out responsibly and following the provisions of the law. One of the North Lampung District Attorney Prosecutor, in an interview conducted by the author, explained that losses could be classified in two forms, namely first, material losses, losses that can be calculated and proven in number as a result of being arrested and detained, prosecuted and tried. Second, immaterial losses are losses that cannot be assessed, such as damage to one's reputation or feelings of shame. ${ }^{14}$

The implementation of pretrial in a limited manner is regulated in Articles 77 to 83 of the Criminal Procedure Code and Articles 7 to 15 of Government Regulation Number 27 of 1983 concerning the Implementation of the Criminal Procedure Code Jo. Government Regulation Number 58 of 2010 concerning Amendments to Government Regulation Number 27 of 1983

\footnotetext{
${ }^{11}$ Heri Purwanto, "Upaya Ganti Rugi Akibat Tidak Sahnya Penangkapan Dan Penahanan Pasca Dikeluarkanya Peraturan Pemerintah No. 92 Tahun 2015 Tentang Pelaksanaan Kuhap,” Jurnal Media Hukum 23, no. 1 (June 30, 2016): 48-61, https://doi.org/10.18196/jmh.2015.0067.48-61.

12 Yuliyanto Yuliyanto, "Problematika Tata Cara Eksekusi Ganti Kerugian Dalam Perkara Pidana," Jurnal Penelitian Hukum De Jure 19, no. 3 (September 30, 2019): 349, https://doi.org/10.30641/dejure.2019.v19.349360.

${ }^{13}$ Dadang Suprijatna, "Analysis Police Efforts in Clear Her Name Due To False Arrest According To Article 1, Item 23 about Rehabilitation Arrest Criminal Code," Jurnal Hukum De Rechtsstaat 1, no. 2 (2015): 93-110, https://doi.org/10.30997/jhd.v1i2.452.

${ }^{14}$ Interview with the North Lampung District Attorney Prosecutor on April 7, 2020, at 10.15 WIB.
} 
concerning Implementation of the Criminal Procedure Code Jo. Government Regulation Number 95 of 2015 concerning the Second Amendment to Government Regulation Number 27 of 1983 concerning the Criminal Procedure Code (PP KUHAP). If you look at the substance of the provision, it is known that it does not contain the complete and adequate mechanism or procedure for administering pretrial.

Regarding this matter, one of the Judge at the Kotabumi District Court explained that until now, there had been no provision that regulates explicitly pretrial procedural law so that the mechanism for conducting pretrial hearings in practice still adheres to the principles and principles in civil procedural law because the compensation claim is a claim for a person's civil rights adopted in the Criminal Procedure Code with the aim that the compensation case can be decided through a criminal trial as the implementation of fast, cheap and straightforward judicial principles. ${ }^{15}$

In line with this opinion, in an interview conducted by the author, the Investigator at North Lampung Police also explained that the pretrial mechanism regulated in the Criminal Procedure Code does not explain the procedural law used. Still, in practice, the procedural law applied in civil procedural law, one of the characteristics is that there is the term applicant and the respondent. Whereas if you look at Article 82 paragraph (1) letter b, it only mentions the term "authorized official" so that it can be understood that the Criminal Procedure Code does not recognize the term respondent, besides that the position of the authorized official is only to provide information to the judge regarding the application or claim submitted by the applicant and not positioned as the respondent. Because in this article, it has been mentioned about the party domiciled as the applicant, namely the suspect, in pretrial practice, the "authorized official" position is referred to as the respondent. ${ }^{16}$

Civil procedural law as the basis for pretrial examination is also known as proof of formal truth incomplete documents or formal letters. It is supported by witness examination with a maximum duration of the examination of 7 (seven) days. ${ }^{17}$ Nevertheless, pretrial is part of law enforcement in the criminal justice system in Indonesia which must be carried out consistently to ensure justice, benefit and legal certainty. ${ }^{18}$

In connection with the claim for compensation due to an error in persona, in this study, the author provides limitations based on the claim for compensation as stipulated in Article 95 paragraph (1), paragraph (3), paragraph (4) and paragraph (5) of the Criminal Procedure Code and correlated with the determination of case Number 1/Pid.Pre/2019/PN.Kb, so that it can be seen that there are limitations conditions that must be met in connection with the submission of claims for compensation, including the following:

a. An applicant is a person who was originally a suspect, defendant or convict and has been arrested, detained and prosecuted without being mistaken about the person (error in persona).

b. Compensation is filed through the court that initially tried the criminal case, and the same judge carried out the examination.

c. The examination is carried out by following the pretrial event.

Mechanism of pre-trial examination for claims for compensation due to an error in persona includes the following matters:

\footnotetext{
${ }^{15}$ Interview with the Judge at the Kotabumi District Court on April 6, 2020, at 14.35 WIB.

${ }^{16}$ Interview with the Investigator at North Lampung Police on April 7, 2020, at 14.00 WIB.

${ }^{17}$ Fachrizal Afandi, "Perbandingan Praktik Praperadilan Dan Pembentukan Hakim Pemeriksa Pendahuluan Dalam Peradilan Pidana Indonesia," Mimbar Hukum - Fakultas Hukum Universitas Gadjah Mada 28, no. 1 (February 15, 2016): 93, https://doi.org/10.22146/jmh.15868.

${ }^{18}$ M Muntaha, "Kedudukan Pra Peradilan Dalam Sistem Hukum Pidana Di Indonesia," Mimbar Hukum - Fakultas Hukum Universitas Gadjah Mada 29, no. 3 (January 12, 2018): 461, https://doi.org/10.22146/jmh.22318.
} 
a. As the victim who suffered losses, the applicant submits an application for compensation to the head of the district court in the district court, which previously examined the applicant's criminal case a maximum of 3 (three) months after the date of the copy of the verdict was received.

b. The head of the district court appoints a single judge, namely one of the judges who originally tried the applicant's criminal case, to preside over the trial with the assistance of 1 (one) clerk.

c. The maximum pretrial period is 7 (seven) days from the start of the trial. The order of the inspection schedule is, the first session of identity examination is followed by reading the contents of the compensation claim; the second trial reads the answer from the respondent; the third trial reads the applicant's replica of the respondent's answer; the fourth session of the duplicate reading of the respondent on the replica of the applicant; the fifth and sixth trial of evidence includes letter evidence from the applicant and the respondent and witness and expert evidence from the applicant and the respondent; and the seventh session reads the contents of the judge's determination. ${ }^{19}$

The following explanation put forward by Judge at the Kotabumi District Court in an interview conducted by the author explained that juridically the Criminal Procedure Code does not regulate the format for writing the contents of the request for compensation, considering that the pretrial administration is carried out with a civil procedure law mechanism, then based on Article 8 paragraph (3) Reglement Op de Burgerlijke Rechts Vordering (RV) the contents of the application must at least contain the following:

a. The identity of the applicant, namely the suspect, defendant or convict and includes the identity of the respondent, namely the head of the investigator or public prosecutor;

b. A description of the reasons or basis for applying (posita) for compensation; and

c. A description of the matters demanded or requested to be decided by the judge (petitum).

In addition, it needs to be emphasized that the judge cannot be used as the respondent in a pretrial case because it refers to the Circular Letter of the Supreme Court of the Republic of Indonesia Number 14 of 1983, which contains the reason that the juridical responsibility for the first act of detention is the responsibility of each agency, if a judge carries out the first detention, it is for examination in court. If there is a request for a pretrial examination of a judge, based on the circular letter, the head of the court can immediately reject the request for pretrial. ${ }^{20}$

In an interview conducted by the author, the Investigator at North Lampung Police explained that the placement of the Chief of Police and the Head of the Prosecutor's Office as the respondent in a formal pretrial case examination was only to provide information to the judge as material for legal considerations to make a decision. The information referred to is stated in the answer and duplicate format containing a rebuttal to the applicant's application. In addition, even though those who were placed as the respondent for the claim for compensation due to an error in persona were the Chief of Police and the Head of the Prosecutor's Office, If the judge grants the claim, then the party who is obliged to make payments is the Minister of Finance as the state treasurer by using funds sourced from the APBN. ${ }^{21}$

In connection with the mechanism for claiming compensation through pretrial due to an error in persona, so to facilitate the analysis, the author uses an example of a claim for compensation filed by Oman Abdurahmah Bin Kasnan in case Number 1/Pid.Pra/2019/PN.Kbu, as well as based on the theory of law enforcement as stated by Muladi,

\footnotetext{
${ }^{19}$ Interview with the Prosecutor at the North Lampung District Attorney on April 7, 2020, at 10.15 WIB.

${ }^{20}$ Interview with the Judge at the Kotabumi District Court on April 6, 2020, at 14.35 WIB.

${ }^{21}$ Interview with the Investigator at North Lampung Police on April 7, 2020, at $14.00 \mathrm{WIB}$.
} 
divides it into 3 (three) stages: formulation, application, and execution. ${ }^{22}$ So it can be analyzed as follows:

\section{a. Formulation Stage}

The formulation stage is the first stage carried out by the legislature. This stage has a strategic role in claiming compensation through pretrial due to an error in persona. At this stage, the legal basis for the implementation of pretrial is formulated. When referring to the case of the claim for compensation filed by Oman Abdurahman Bin Kasnan, it is known that the granting of the compensation claim was based on juridical reasons in the form of:

- There is the authority of the district court to examine and adjudicate claims for compensation through a pretrial mechanism based on Article 77 of the Criminal Procedure Code to Article 83 of the Criminal Procedure Code.

- There is a right to obtain compensation for the in-person error experienced by Oman Abdurahman Bin Kasnan as stipulated in Article 95 paragraph (1) of the Criminal Procedure Code;

- There is a determination of the amount of compensation received by Oman Abdurahman Bin Kasnan as stipulated in Article 9 paragraph (2) of the Criminal Procedure Code.

\section{b. Application Stage}

The application stage is the second stage implemented through the implementation of pretrial hearings by judges who carry out judicial functions. The authority to carry out pretrial within the scope of examining and adjudicating compensation claims due to errors in persona is based on absolute competence as regulated in Article 77 of the Criminal Procedure Code, Article 78 of the Criminal Procedure Code, Article 82 paragraph (1) and paragraph (4) of the Criminal Procedure Code, Article 95 paragraph (1), paragraph (3), paragraph (4) and paragraph (5) of the Criminal Procedure Code.

\section{c. Execution Stage}

The execution stage is the third stage implemented through the administrative process of disbursing compensation following the amount stipulated in the judge's decision. The mechanism for disbursement of compensation money is carried out based on the Decree of the Minister of Finance of the Republic of Indonesia Number 983/KMK.01/1983, covering:

- The head of the court applies to the provision of funds to the Minister of Law and Human Rights of the Republic of Indonesia by attaching a pretrial judge's stipulation or decision;

- The Minister of Law and Human Rights of the Republic of Indonesia submits a request for the issuance of an Authority Decree or Surat Keputusan Otoritas (SKO) to the Minister of Finance of the Republic of Indonesia;

- The Minister of Finance of the Republic of Indonesia issues an SKO at the expense of the financing section and the calculation of the routine state budget;

- The SKO is conveyed to the applicant for compensation;

- The claimant for compensation submits a payment request to the Head of the State Treasury via the court's head, who examines the claim for compensation through the pretrial by attaching the SKO and the pretrial judge's decision or determination.;

- The head of the court forwards to the Head of the State Treasury accompanied by a Letter of Request for Payment;

- The Head of the State Treasury Office issues a Payment Order to the applicant for compensation.

${ }^{22}$ Muladi, Kapita Selekta Sistem Peradilan Pidana (Semarang: Badan Penerbit Universitas Diponegoro, 1995): 13-14. 


\section{Inhibiting Factors in Pretrial Judges' Decisions Implementation on Granting Claims for Compensation}

Law is a means of legitimizing the formal power of state institutions, government units, as well as state and government officials, ${ }^{23}$ So that every action or policy must be carried out according to the rule of law, the legal rules related to compensation were first formulated in Article 9 of Law Number 14 of 1970 concerning the Basic Provisions of Judicial Power. ${ }^{24}$ Furthermore, starting from the promulgation of the Criminal Procedure Code claims for compensation within the scope of criminal law have been regulated separately, which can be requested through a pretrial mechanism.

Compensation is compensation for all types and degrees of loss suffered by the victim, be it physical, psychological or social losses, including the costs required for the victim's recovery. ${ }^{25}$ The right to file a claim for compensation through pretrial is a manifestation of human rights and dignity protection. ${ }^{26}$ The submission of a claim for compensation due to an error in persona based on the reasons of Article 95 paragraph (1) of the Criminal Procedure Code is submitted after the inkracht decision on the criminal case in question, a maximum of three months after the decision is received.

As for the amount of compensation due to errors in a persona that can be applied legally, it is regulated in Article 9 of the PP KUHAP, among others:

a. A minimum of Rp.500,000 (five hundred thousand rupiahs) and a maximum of Rp.100,000,000 (one hundred million rupiahs);

b. If it results in severe injury or disability so that it is unable to carry out work, a minimum of Rp.25,000,000 (twenty-five million rupiahs) and a maximum of Rp.300,000,000 (three hundred million rupiahs);

c. If it results in death, a minimum of Rp. 50,000,000 (fifty million rupiahs) and a maximum of Rp. 600,000,000 (six hundred million rupiah).

The pretrial decision is in the form of a determination divided into two forms: firstly, rejecting the applicant's pretrial application (partially and or completely), and secondly, accepting the applicant's pretrial application (partially and or completely). ${ }^{27}$ The substance of the determination must be implemented immediately in connection with the grant of the claim for compensation due to an error in persona, the amount of compensation being stated in the pretrial judge's determination. Investigator at North Lampung Police, in an interview conducted by the author, explained that the payment of the amount of compensation that the pretrial judge

\footnotetext{
${ }^{23}$ Fithriatus Shalihah and Oksep Adhayanto, "Hukum, Moral, Dan Kekuasaan Dalam Telaah (Hukum Adalah Alat Teknis Sosial)," Fiat Justisia Jurnal Ilmu Hukum:Jurnal Ilmu Hukum 10, no. 4 (April 12, 2017): 671, https://doi.org/10.25041/fiatjustisia.v10no4.735.

${ }^{24}$ Hatlyinsyanna Seroy, "Perlindungan Hukum Terhadap Korban Salah Tangkap Dari Sudut Pandang Kuhap," Lex Crimen 5, no. 5 (2016): 134-42, https://ejournal.unsrat.ac.id/index.php/lexcrimen/article/view/13301/12885.

${ }^{25}$ Shynta Soplantila, "Penerapan Hak Ganti Rugi Terhadap Korban Salah Tangkap Menurut PP Nomor 92

Tahun 2015," Lex Crimen 6, no. 10 (January 31, 2018): 39-47, https://ejournal.unsrat.ac.id/index.php/lexcrimen/article/view/18868.

${ }^{26}$ Intan Maharani Putri and Warih Anjari, "Ganti Kerugian Terhadap Korban Salah Tangkap Dalam Perkara Pidana: Studi Putusan Nomor 1273/Pid.B/2013/Pn.Jkt.Sel Juncto Penetapan Nomor 98/Pid.Prap/ 2016/Pn.Jkt.Sel," LEX CERTA 5, no. 1 (May 28, 2019): 1-20,

http://journal.uta45jakarta.ac.id/index.php/lexcerta/article/view/1569.

27 Safrun Kafara, “Analisis Hukum Pelaksanaan Putusan Praperadilan Terhadap Perkara Setya Novanto Oleh Komisi Pemberantasan Korupsi (Nomor 97/Pid.Prap/2017/PN.Jkt-Sel Tanggal 29 September 2017)," Jurnal Penegakan Hukum Dan Keadilan 1, no. 1 (February 19, 2020): 81-94, https://doi.org/10.18196/jphk.1105.
} 
had determined was carried out by the state through the Head of the State Treasury Service Office or Kepala Kantor Pelayanan Perbendaharaan Negara (KKPN) on behalf of the Minister of Finance of the Republic of Indonesia which was budgeted from the APBN or state budget. ${ }^{28}$

Furthermore because the compensation payment was sourced from the State Budget, in practice, the payment could not be made immediately because the budget was not necessarily available. Hence, it had to be submitted and allocated in advance in the DIPA, which was explicitly intended to make intended compensation payments. This often delays the payment of compensation, mainly based on the Decree of the Minister of Finance of the Republic of Indonesia Number 983/KMK.01/1983 concerning Procedures for Payment of Compensation, the disbursement process is carried out through several relatively long stages. ${ }^{29}$

Based on the results of the research conducted, related to the inhibiting factors in the implementation of the pretrial judge's determination on the granting of the compensation claim, it can be analyzed using the theory of inhibiting factors proposed by Soerjono Soekanto, including the factors of legislation, law enforcement officers, facilities and facilities, society, and culture. ${ }^{30}$ The most dominant and relevant factor in this research is the statutory factor.

Although Article 11 paragraph (2) of the PP KUHAP has determined that the payment of compensation shall be made within a maximum period of 14 (fourteen) from the receipt of the request for compensation by the Minister, however, the problem is that the payment procedure is carried out by referring to the Decree of the Minister of Finance of the Republic of Indonesia Number 983/KMK.01/1983 which regulates administrative procedures that are pretty long and convoluted to involve central government agencies, namely the Ministry of Finance of the Republic of Indonesia and the Ministry of Law and human rights. This, of course, takes quite a long time. In addition, the process also does not have a clear timeline. Although it can be done quickly, the payment of compensation is also very dependent on the availability of the budget contained in the DIPA. If the budget is not available, the new payment can be made in the following year because it must be budgeted in advance in the DIPA. This obstacle deserves the attention of the Supreme Court of the Republic of Indonesia and the Ministry of Finance of the Republic of Indonesia to provide solutions to facilitate the process of paying compensation to pretrial applicants to create justice and legal certainty.

\section{Conclusion}

Based on the problems and discussions described above, the authors conclude that the mechanism for claiming compensation through pretrial due to an error in persona in the implementation of the criminal justice system is carried out in 3 (three) stages, including:

a. The formulation stage is the stage implemented by the legislative body through the formulation of the Criminal Procedure Code as the basis for the mechanism for examining pretrial cases.

b. The application stage, which is the stage that is implemented through the implementation of pretrial hearings by judges as law enforcers who carry out judicial functions

c. The execution stage, which is the stage that is implemented through the administrative process of disbursement and payment of compensation to the applicant under the amount determined by the pretrial judge in his decision.

Whereas the inhibiting factor in the implementation of the pretrial judge's determination on the granting of the compensation claim is influenced by statutory factors, namely the Decree of the Minister of Finance of the Republic of Indonesia Number 983/KMK.01/1983, which regulates the administrative procedure is quite long. It involves the Minister of Finance of the

\footnotetext{
${ }^{28}$ Interview with the Investigator at North Lampung Police on April 7, 2020, at 14.00 WIB.

${ }^{29}$ Interview with the Prosecutor at the North Lampung District Attorney on April 7, 2020, at 10.15 WIB.

${ }^{30}$ Soerjono Soekanto, Faktor-Faktor Yang Mempengaruhi Penegakan Hukum (Bandung: Raja Grafindo Persada, 2007): 8.
} 
Republic of Indonesia and the Minister of Law and Human Rights of the Republic of Indonesia, so that takes a long time, besides that its implementation also depends on the availability of the budget contained in the DIPA if the budget is not available then the new payment can be carried out in the following year because it must be budgeted first in the DIPA.

\section{Bibliography}

\section{A. Books}

Muladi. Kapita Selekta Sistem Peradilan Pidana. Semarang: Badan Penerbit Universitas Diponegoro, 1995.

Soekanto, Soerjono. Faktor-Faktor Yang Mempengaruhi Penegakan Hukum. Bandung: Raja Grafindo Persada, 2007.

\section{B. Journals}

Afandi, Fachrizal. "Perbandingan Praktik Praperadilan Dan Pembentukan Hakim Pemeriksa Pendahuluan Dalam Peradilan Pidana Indonesia." Mimbar Hukum - Fakultas Hukum Universitas Gadjah Mada 28, no. 1 (February 15, 2016): 93. https://doi.org/10.22146/jmh.15868.

Alfitra, Alfitra. "Disparitas Putusan Praperadilan Dalam Penetapan Tersangka Korupsi Oleh KPK." Jurnal Cita Hukum 4, no. 1 (June 21, 2016): 73-86. https://doi.org/10.15408/jch.v4i1.3201.

Amdani, Yusi. "Implikasi Penafsiran Undang-Undang Oleh Hakim Praperadilan Dalam Perkara Tindak Pidana Korupsi." Mimbar Hukum - Fakultas Hukum Universitas Gadjah Mada 27, no. 3 (February 10, 2016): 459. https://doi.org/10.22146/jmh.15872.

Benda-Beckmann, Keebet von, and Bertram Turner. "Legal Pluralism, Social Theory, and the State.” Journal of Legal Pluralism and Unofficial Law 50, no. 3 (September 2, 2018): 25574. https://doi.org/10.1080/07329113.2018.1532674.

Hasuri, Hasuri. "Sistem Peradilan Pidana Berkeadilan Melalui Pendekatan Kontrol Dalam Proses Penegakan Hukum.” Ajudikasi : Jurnal Ilmu Hukum 3, no. 2 (December 31, 2019): 167-84. https://doi.org/10.30656/ajudikasi.v3i2.1879.

Kafara, Safrun. "Analisis Hukum Pelaksanaan Putusan Praperadilan Terhadap Perkara Setya Novanto Oleh Komisi Pemberantasan Korupsi (Nomor 97/Pid.Prap/2017/PN.Jkt-Sel Tanggal 29 September 2017).” Jurnal Penegakan Hukum Dan Keadilan 1, no. 1 (February 19, 2020): 81-94. https://doi.org/10.18196/jphk.1105.

Krulichová, Eva. "Changes in Crime-Related Factors and Subjective Well-Being over Time and Their Mutual Relationship." International Journal of Law, Crime and Justice 65 (June 1, 2021): 100-457. https://doi.org/10.1016/j.ijlcj.2021.100457.

Machura, Stefan, Fay Short, Victoria Margaret Hill, Catherine Rhian Suddaby, Ffion Elena Goddard, Sophie Elisabeth Jones, Emma Louise Lloyd-Astbury, Luke Richardson, and Chernise Alexandra Rouse. "Recognizing Modern Slavery." Journal of Human $\begin{array}{llllll}\text { Trafficking } 5, & \text { no. } 3 \text { (July } 3, \quad 2019):\end{array}$ https://doi.org/10.1080/23322705.2018.1471863.

Muntaha, M. "Kedudukan Pra Peradilan Dalam Sistem Hukum Pidana Di Indonesia." Mimbar Hukum - Fakultas Hukum Universitas Gadjah Mada 29, no. 3 (January 12, 2018): 461. https://doi.org/10.22146/jmh.22318.

Oostinga, M.D., Ellen Giebels, and Paul J. Taylor. "Communication Error Management in Law Enforcement Interactions: A Receiver's Perspective.” Psychology, Crime \& Law 24, no. 2 (2018): 134-55. https://doi.org/10.1080/1068316X.2017.1390112. 
Petrich, Damon M. "A Self-Determination Theory Perspective on Human Agency, Desistance from Crime, and Correctional Rehabilitation." Journal of Developmental and Life-Course Criminology 6, no. 3 (September 1, 2020): 353-79. https://doi.org/10.1007/s40865-02000141-9.

Purwanto, Heri. "Upaya Ganti Rugi Akibat Tidak Sahnya Penangkapan Dan Penahanan Pasca Dikeluarkanya Peraturan Pemerintah No. 92 Tahun 2015 Tentang Pelaksanaan Kuhap." Jurnal Media Hukum 23, no. 1 (June 30, 2016): 48-61. https://doi.org/10.18196/jmh.2015.0067.48-61.

Putri, Intan Maharani, and Warih Anjari. "Ganti Kerugian Terhadap Korban Salah Tangkap Dalam Perkara Pidana: Studi Putusan Nomor 1273/Pid.B/2013/Pn.Jkt.Sel Juncto Penetapan Nomor 98/Pid.Prap/ 2016/Pn.Jkt.Sel.” LEX CERTA 5, no. 1 (May 28, 2019): 1-20. http://journal.uta45jakarta.ac.id/index.php/lexcerta/article/view/1569.

Rohman, Syarif Abdul, and Umi Rozah. "Kebijakan Kriminal Mengenai Pemberian Ganti Kerugian Terhadap Korban Salah Tangkap.” Jurnal Pembangunan Hukum Indonesia 2, no. 1 (January 10, 2020): 117-28. https://doi.org/10.14710/jphi.v2i1.117-128.

Seroy, Hatlyinsyanna. "Perlindungan Hukum Terhadap Korban Salah Tangkap Dari Sudut Pandang Kuhap." Lex Crimen 5, no. 5 (2016): 134-42. https://ejournal.unsrat.ac.id/index.php/lexcrimen/article/view/13301/12885.

Setiawan, Ahmad Nur. "Hak Tersangka Menuntut Ganti Kerugian Atas Penahanan Yang Tidak Sah.” DiH: Jurnal Ilmu Hukum 14, no. 0 (August 1, 2018). https://doi.org/10.30996/dih.v0i0.1791.

Seubert, Sandra. "Shifting Boundaries of Membership: The Politicisation of Free Movement as a Challenge for EU Citizenship.” European Law Journal 26, no. 1-2 (March 1, 2020): 4860. https://doi.org/10.1111/eulj.12346.

Shalihah, Fithriatus, and Oksep Adhayanto. "Hukum, Moral, Dan Kekuasaan Dalam Telaah (Hukum Adalah Alat Teknis Sosial)." Fiat Justisia Jurnal Ilmu Hukum:Jurnal Ilmu Hukum 10, no. 4 (April 12, 2017): 671. https://doi.org/10.25041/fiatjustisia.v10no4.735.

Soplantila, Shynta. "Penerapan Hak Ganti Rugi Terhadap Korban Salah Tangkap Menurut PP Nomor 92 Tahun 2015." Lex Crimen 6, no. 10 (January 31, 2018): 39-47. https://ejournal.unsrat.ac.id/index.php/lexcrimen/article/view/18868.

Suprijatna, Dadang. "Analysis Police Efforts in Clear Her Name Due To False Arrest According To Article 1, Item 23 about Rehabilitation Arrest Criminal Code." Jurnal Hukum De Rechtsstaat 1, no. 2 (2015): 93-110. https://doi.org/10.30997/jhd.v1i2.452.

Yuliyanto, Yuliyanto. "Problematika Tata Cara Eksekusi Ganti Kerugian Dalam Perkara Pidana." Jurnal Penelitian Hukum De Jure 19, no. 3 (September 30, 2019): 349. https://doi.org/10.30641/dejure.2019.v19.349-360.

\section{Regulations}

Decision of Kotabumi District Court Number 15/Pid.B/2018/PN.Kbu.

Decree of the Minister of Finance of the Republic of Indonesia Number 983/KMK.01/1983 concerning Procedures for Payment of Compensation.

Government Regulation Number 95 of 2015 concerning the Second Amendment to Government Regulation Number 27 of 1983 concerning the Criminal Procedure Code.

Law No. 8/1981 on the Law of Criminal Procedure.

Supreme Court Decision Number 129 K/Pid.2019. 
Mechanism of Compensation...

Feryando 